\title{
The Role of IGAD (Intergovernmental Authority for Development) in Facilitating Civil War Peace Settlements in the Horn of Africa
}

\author{
Anwar Ayano Idris \\ Raya University, College of Social science Department of History and Heritage Management
}

\begin{abstract}
The aim of this study was critically examine "The role of IGAD (Intergovernmental Authority for Development) in facilitating civil war and peace settlements in the regions" horn of Africa. The political geography of the Horn of Africa primarily encompasses South Sudan, Ethiopia, Eritrea, Djibouti, Somalia, Kenya and Uganda. The regional formation of the Horn has been constructed by variety of natural internal and external factors and forces. The multiplicity of internal and external problems and challenges faced by the sub region that is civil war, violent power struggle, war lordism, and state collapse, natural disaster and cold war conflict and super power rivalries played out in the Horn have led to further reconstruction and expansion of the region. The term greater Horn of Africa is used to describe the common problems faced by the Horn countries and East Africa has hegemonic ally constructed.
\end{abstract}

Keywords: IGAD, Civil War, Peace settlement, Horn of Africa

DOI: $10.7176 /$ IAGS/78-02

Publication date: December $31^{\text {st }} 2019$

\section{Introduction}

The Horn of Africa has distinguished itself and example of hopeless continent or a continent of war with itself. Horn of Africa is an area of famine, drought, poverty and starvation, civil conflicts and interstates wars as well as political instability. It is also called the deadliest conflict cluster in the world. The sub region hosts some of the longest running civil wars, fought in some of the world's poorest countries. This wars and political instabilities have produced estimated 2.5 causalities. The push and pull factors of migration have also led to massive refugee flows. The region of the Horn of Africa has the largest number of displaced persons in the world.

The Horn of Africa is also characterized by dependence on international humanitarian agencies, relief organizations and UN agencies for crisis and development interventions. The most crucial country vulnerable to international humanitarian emergency is Darfur region in western Sudan where pro-government militias, the Janaweed, are accused of perpetuating genocide and massive humanitarian disaster. The UN has described the problems in Darfur as the world's worst humanitarian crisis. Famine, wars and political instability in the region demonstrate the regionalization of civil wars and natural disaster in the Horn.

However, the Horn hasn't been paralyzed by countless problems and challenges facing the region. Out of these difficult problems, the region has developed mechanisms to respond. The role of IGAD (Intergovernmental Authority for Development) in facilitating civil war peace settlements in the regions as well as the role of institutions such as UN, EU, AU and extra regional actors in assisting the process of peace keeping and conflict management in the Horn of Africa.

Historically, the Intergovernmental Authority on Drought and Development (IGAD) was established in 1986 comprising Ethiopia, Djibouti, Kenya, Sudan, and Uganda. The circumstance giving rise to the formation of IGAD were the rampant drought and desertification that was ravaging the region (IGAD). Since the early 1970s the region has been experiencing pervasive and serve droughts such as those of 1974 and 1984. These droughts inevitably generated extreme environmental degradation, desertification and famine, making livelihoods in the region extremely precarious. The famine of $1984 / 5$

The core argument is that the multiplicity of security threats and risks and their devastating consequences have forced the region to attempt to build regional peace and security systems to respond to these diverse problems. But this regional response to peace and security challenge raises several critical issues:

\subsection{Political Economy of the Horn of Africa}

The political geography of the Horn of Africa primarily encompasses Sudan, Ethiopia, Eritrea, Djibouti, Somalia, Kenya and Uganda. The regional formation of the Horn has been constructed by variety of natural internal and external factors and forces. The multiplicity of internal and external problems and challenges faced by the sub region that is civil war, violent power struggle, war lordism, and state collapse, natural disaster and cold war conflict and super power rivalries played out in the Horn have led to further reconstruction and expansion of the region. The term greater Horn of Africa is used to describe the common problems faced by the Horn countries and East Africa has hegemonic ally constructed. The description greater Horn of Africa is used in this context to describe the spheres of political, economic, security and strategic self-interest of the united states and western interests in the Horn as well as the east and the great lakes regions. The Greater Horn of Africa includes ten 
countries i.e. the original seven plus the Democratic Republic of Congo, Tanzania and Rwanda.

There is great diversity in ecological, political, socio-cultural and economic terms in the Horn of Africa. The region is characterized by high population growth, with population density varying from country to country. The majority of population depends on subsistence agriculture and pastoralist. Pastoralism is an important production system in the region. The globe's huge concentration of pastoralism is found in Sudan, because, the largest part of the land is arid and semi-arid land. The region is affected by famine, droughts and floods. A mid pastoralist groups clash over the use of access to water and pasture resources. The region is also affected by degradation including desertification, deforestation, water scarcity and watershed degradation. The widespread clashes and conflicts in the region have also led to serious problems of landmines and their devastating effects on agricultural, economic and commercial activities. The environmental problem is compounded by oil extraction and oil exploration activities in southern Sudan.

Even though Horn Africa has resources including substantial oil and gas reserves and diverse ecosystems, the region continues to produce poor economic growth. The majority of states in the Horn of Africa implemented structural adjustment programs, with varying degree of success. The diversity in the level of development in the Horn of Africa countries reflected in their economic and social indicators. According to the UNDP, Human Development Index 2003, only Sudan is in the medium Human development category and the rest of the Horn countries are in the low Human development category. The GDP per capital of Djibouti at US dollar 2370 (2001) is sharply contrasted with the GDP per capital of the hegemonic pretender, Ethiopia, of US dollar 810 (2001).

The region has been plagued by inevitability of famine. In 1960s Sudan and Eritrea were well known in massive refugees to the neighbors due to civil war. The internationally recognized famine in Ethiopia of 1973 74 was severe. Humanitarian emergency has distinguished the region of Horn of Africa as famine. The most celebrated international response to international media coverage of the Ethiopia famine was Bob Geldovs "Live Aid" which mobilized international support and humanitarian assistance for the famine in Ethiopia. The perception of the Horn as unstable region and disaster relief zone is aggravated by multiplicity of wars and armed conflicts in the region. Famine and wars has exacerbated refugees flow to the neighbors. Then it threatened the peace and security of the neighboring regions. Armed conflict of Ethiopia and Eritrea war as well as protracted civil war and state collapse in Somali, Sudan and Uganda are some of the examples.

Beside this, colonial rule and its legacy left the people of Somalia divided and shared among countries such as Ethiopia, Djibouti, and Kenya. This led to interstate wars and border disputes with its neighbors in 1970s in attempt to create greater Somaliland. Eritrea had to fight 30 years to secure her independence. In addition, there had been a variety of military intervention in Sudan, Ethiopia and Somalia. The countries in the region have developed the habit of supporting rebels and guerrilla groups against their neighbors. Famine aggravated the problems and this led to the fall of Hailesillasie of Ethiopia and Limeira of Sudan.

The geo-strategic location of the Horn and its proximity to the Middle East, Arabian Peninsula and Islamic world meant that the region attracted a variety of regional and international conflicts. Extra regional actors have plated a destructive role in underdevelopment and insecurity prevalent in the Horn of Africa. Britain, France and Italy had sphere of influence during the colonial era.

However, in the post-cold war era, USA and USSR are come to the region cold war ideological impact led to the establishment of different political systems including military dictatorships. For example, garrison socialism in Ethiopia. Cold war rivalry let to the establishment of military bases and global communications and intelligence bases and networks in the region. There was an estimated seven billion US dollar soviet building of arms in Ethiopia in the 1980s, where as in the Sudan US military aid and training amounted to US dollar 1.4 billion. During this time both US and USS and supported dictatorial leaders for their own interests. The end of the cold war later changed the political map and conflict landscape of the Horn with independence of Eritrea in 1993 and the breakup of Somalia in to warlord fiedoms and separate nations. Because of the Horn has influenced to the middle east, it has been centers of Islamic fundamentalism with links to terrorist network and operations.

The oil producing middle east, the approximating of the Horn to international water ways, the security interest of the state of Israel and the Palestinian people and the strategic interests of the major powers have all affected the Horn and further instigated wars, conflicts and insecurity, in the region. The region has links between food and environmental insecurity, conflicts, bad governance and underdevelopment.

\subsection{From Famine to Regional Peace and Security Architecture: Intergovernmental Authority on Development (IGAD)}

Factors that forced the Horn of African countries to create regional systems are the environmental and development problems and challenges faced by the Horn countries so as to address these regional problems. This led to the creation of Intergovernmental Authority for Development and Drought (IGADD) in 1986 with a mandate focusing on drought, famine and desertification in the region. IGADD also provided a regional platform for political dialogue on regional peace and security issues. The resurgence of regionalism in world politics caused IGADD to consider the potential benefit from regional economic integration and cooperation on peace 
and security issues in the Horn. In this case, in 1995, IGADD held a meeting in Addis Ababa. The decision was taken to expand regional cooperation in the Horn. Also, IGADD held a meeting in 1996 in Nairobi. In this meeting, IGADD adopted the agreement establishing the Intergovernmental Authority on Development (IGAD). The four primary area of focus of IGAD were:-

1. Food security

2. Environmental protection

3. Infrastructural development (transport and communications)

4. Regional conflict prevention, management and resolution and humanitarian affairs.

The aim of IGAD is to promote regional peace and stability as the foundation for attaining the goals of food security, environmental protection and sustainable development. IGAD was made as one of pillars of the African Economic Community (AEC).To institutionalize cooperation with regional peace and security issues, the protocol on the establishment of a Conflict Early Warning and Response Mechanism (CEWRM) was adopted on January 2002. CEWARN became operational in September 2002 in Addis Ababa. CEWARN has established regional early warning units in each IGAD member state. IGAD has also created a committee on early warning of conflicts and insecurity in the region. The function of CEWARN has been:-

- To receive and share information concerning potentially violent conflict

- To give early warning and response including exchange of information and response among member states based on the principle of timeless, transparency and cooperation and free flow of information.

- Gathering, verifying, analyzing information and communicating results to decision makers in IGAD's policy organ and national government member states.

- To respond by taking appropriate action at national and regional levels, to prevent, mitigate and manage conflicts.

The problem, in the Africa, is not about lack of adequate information or early warning, but failure of early response. From the genocide in Rwanda to the bloody civil wars and state collapse in both Liberia and Serra Leone has not been lack of early warning to prevent the outbreak of these conflicts and mass murder, but primarily lack of early responses. In this conflict, IGAD lacks the mandate to force the member states to take appropriate action. For example, despite pressure from international bodies, IGAD couldn't force the Sundance government to prevent the humanitarian emergency in the Darfur region conflict early warning; CEWARN is similar to the ECOWAS conflict early warning program in West Africa. But there was no sharing of ideas and information between two. Both are extremely funded programs.

IGAD's expansion into the peace and security domain and its attempts build regional systems is framed within the concept and practice of preventive diplomacy. It was the need to prevent escalation of the conflict not to involve superpowers and their allies. It was how to avert regionalism civil wars.

\subsection{IGAD and Preventive Diplomacy in the Horn of Africa: Peace Keeping in Sudan and Somalia}

The IGAD conference in strengthening the role of IGAD in regional peace initiatives and post conflict reconstruction in December 2003 in Nairobi considered the expansion of the role of CEWARN not to cover pastoralist conflicts but also to include the role of member states in preventive diplomacy in the Horn.

The role and contribution of IGAD chair is preventive diplomacy. Art. 18 of IGAD underscored the commitment of the Horn countries to preventive diplomacy orientations and the building of regional peace and security system in sub region. They believe this is the key to economic and social progress.

IGAD attempted to bring peace in Sudan and Somalia as well as Ethiopia-Eritrea war. Ethio-Eritrea war in 2000 refocused international attention on the region. Interstate wars are increasingly seen in world politics. It was a sign of political underdevelopment and weakness of regional mediation efforts. Conflicts going in these two countries further aggravated peace process problem in the Horn of Africa. Both Ethiopia and Eritrea actively and covertly supported internal conflicts and political instability in each other's country by supporting insurgency and dissident groups. Ethiopia supported ELF (Eritrean Liberation Front) and Eritrea supported OLF (Oromo Liberation Front) and other anti Meles Zenawi rebel factions. The next door neighbor, Djibouti was punished by Eritrea for its support to the Ethiopia war effort. Eritrea supported dissident groups, which sparked off the Afar ethic group rebellion in Djibouti. The UN Security Council banning army sales to both Ethiopia and Eritrea allowed alternative army supply former eastern bloc countries. The war has been simplified as a border conflict; however, the IISS argued that the reason for the war could be attributed to region legitimacy, state sovereignty, nation building, currencies and access to port facilities. The war also involves the personal pride of the two leaders, Meles Zenawi of Ethiopia and Isayas Afework of Eritrea. The disputed region of Badme in north western region of Ethiopia remained a flash point for two countries. IGAD, the AU and EU were involved in conflict prevention. This led to UN forces deployment on the boarder to keep the peace.

\subsection{Sudan Peace Process and Peace Settlement}

In Sudan, civil war had been one of the longest civil war. It was violent confrontations between Muslim Arab 
north and Christian animist south, the majority of who are block Africans. But the post-colonial history of Sudan is littered with wars and conflicts. The cause of the war has been attempt at Islamazation by Sudan government north to Christian south. The government of Sudan imposed Sharia law across the whole of the country, including the Christian dominated south since independence (1956). This accounted for the rebel of south Christian with the formation of Sudanese people's liberation front, demanding independence from the Islamic north. Some political analysts describe the war in Sudan as Ethio-religions war or identity based interstate conflict, whereas others perceive the war as secession war or resource based conflict given the fact that the oil in the southern Sudan has been a major factor in the conflict between north and south of the country. As a result of the conflict, about four millions of Sudanese has become refugees. The involvement of IGAD in peace making process started in 1994, when it mediated the peace talks between the Khartoum government and the SPLA rebel movement. This led to the creation of Front Line State (FLS) consisting of Kenya, Uganda, Ethiopia and Eritrea, mandated with the responsibility to mediate the Sudanese civil war.

However, the front Line states themselves had low intensity civil wars allegedly supported by Sudan. The mediators wanted for border security interest rather than for keeping peace for Sudanese civil. They passed are solution that the importance of national unity under secularism and the recognition of the right of selfdetermination for the south. Disagreement on resolution led to withdrawal of Khartoum's government and collapse of peace initiatives. By 1995, FLS accused of Khartoum as being the main source of regional instability. To illustrate its belligerence, UN and others started to supply covert military and logistical support to the SPLA. In 1997, IGAD revived peace talks. Kenya played the leading as peace making process and peace process war chaired by Kenyan president Daniel Arrapi Moi. Kenya provided political leadership financial and technical support in facilitating peace process.

To facilitate peace process, Moi appointed special envoy. IGAD's peace process moves brought the two closer dialogues and consolidated the peace process. After ten years protracted peace talks, the Kenyan led peace process finally succeeded in negotiating a civil war peace settlement on 26 may 2004. The peace agreement was national unity based on power sharing with SPLA leader as $1^{\text {st }}$ president, John Grang was sworn in as $1^{\text {st }}$ vice president of Sudan in July 2005. He tragically died, three weeks later in helicopter crash, sparking violent demonstrations in Khartoum by pro-SPLM supporters. Later Sudanese peace process has got a doubt because pro government militias in the Darfur region Sudanese government and Janjaweed militias committed suicide in close border of Darfur. Some politician's analysis the crisis as individual interest in pro-government Later, All army was deployed on around the Darfur in 2005-NATO as also giving logistic and technical supper to the AU army.

\subsection{Somalia Peace Process}

The state of Somalia has been collapsed after the overthrow of Seid Barre. This was caused by rival warlords to control power and fiefdoms. Some are one people with common language, culture, ancestry and religion. The root cause of the war was Said Barrie's regime supported by cold war rivalry in the Horn. There was also difference between the post-colonial state and the nature and structure of Somali civil society based on clan system of decentralized governance, and the effect of the end of the cold war. Civil war led to the humanitarian emergency. This led to US led UN force involvement to create safe relief corridor in the war torn Somalia. USLed UN force had the mandate of disarming the militias and warlords. In 1993, the killing of US soldiers led to the withdrawal of American forces and the closing down of UN operations. Therefore, peace settlements remained elusive.

Peace process by IGAD started in 1986. IGAD was disappointed by lack of progress towards peace and national reconciliation in Somalia since warlord not interested in peace. Beside IGAD's under Front Line State, others such as the US, Yemen, Italy, Egypt involved in the Somalia peace process for strategic and historic reasons. IGAD mandated Ethiopia to facilitate peace process a Somalia. In 1998, IGAD and its partner held the Rome conference to assist Ethiopia's peace and reconciliation efforts in Somalia. Ethiopia's diplomatic security reasons were the recurrent factors warranting military incursions into Somalia.

Major obstacles to peace process were the recurrent questions and concerns about the neutrality and impartiality of Ethiopia as an honest peace broker given its involvement in civil war. The Ethiopia-Eritrea war was expanded by proxy in to Somalia with both countries supporting different warring factions and warlords. Ethiopia's domestic security concerns were current factor warranting military incursions into Somali. In 1996, Ethiopia made a military incursion into the Gedo region in support of the Somalia National Front (SNF) in its struggle with the Islamic fundamentalist group, Alitihad, Ethiopia fear of Islamic fundamentalism on its border and prospects of Alithad-backed terrorist activities in Ethiopia led to the 1999 military incursions. IGAD secured support of international financial, diplomatic and political support. IGAD also got the support of regions in Somalia committed to peace, stability and national reconciliation. In addition, IGAD proposed the building block approaches for Somalia. They also proposed to establish regional authorities for decision making at local level to serve as foundation for available nation state. Somaliland (North West) and punt land (Northeast) was perceived 
as peace process building blocks.

Early peace broken by Kenya in 1996 was not implemented Ethiopia sponsored peace process and Cairo conference 1997 was able to agree on the formation of national unity government. The peace process was restarted with the involvement of President Ismail Omar Guelleh of Djibouti who raised the Somali peace process at UN Security Council. IGAD backed conference of 2000 led to the formation of Transitional Nation Government (TNG) with Abdikasim Salam Hassan as president. Kenya had played the lead-nation in facilitating peace process in Somalia. In 2004, after the safari park conference, the final phase of the Somali peace process is now well underway led by Mwi kibaki of Kenya. However, there were difficulties, challenges, and ever change dynamics of Somali politics.

In the efforts to set up the credible government in Somalia and to strengthen the authority of the new government, IGAD-AU deployed peacemaking and peace support operation mission in Somalia. The parliament of Somalia exiled to Kenya elected Abdulahi Yesuf as a new president of Somalia. Efforts at transplants the new government was difficult. Therefore, AU decided to deploy army for peace process in Somalia in 2005.

\subsection{United Nations, Africa Union and External Actors in IGAD led Peace Process in the Horn of Africa.} In facilitating peace process in the Horn, IGAD has taken the principle of "Try Africa First Approach". Peace process in the Horn has its own limitations in terms of resources and expertise, so that it worked with external regional actors and sub-regional actors. Kenya under President Daniel Arrap Moi and Mwi Kibaki activity involved as peace broken in the Horn. But the question is that why the involvement of UN was has been taken as necessity. UN learnt from Somali Peace Process that peace can't be ensured by force, needs time. Therefore, UN turned its attention to humanitarian assistance including relief supplies to refugees and democratic support key role in the Sudanese peace process as observer. As a result, UN facilitated the commitment and support of humanitarian relief agencies and do nor communities to assist in facilitating peace process.

\section{Conclusion}

In facilitating peace process in the Horn, IGAD has learnt harsh lesson. IGAD was able to provide procedures for international coordination and humanitarian assistance in Sudan and Somalia. IGAD depended on Western countries to resource its peace process in the Horn. The problem of IGAD in facilitating peace process in the Horn has its in partiality and neutrality in the reconciliation efforts. Sudan at the beginning refused to accept the peace process, because she condemned IGAD member states for taking sides with SPLA. Only Kenya and Djibouti was declared neutral in the Sudanese conflict. Therefore Kenya plays a role in facilitating peace process. But, Khartoum government still didn't trust Kenya as peace broker.

IGAD's preventive diplomatic intervention has been hampered by lack of resources, and hence external dependence. IGAD lost collective approaches to peace and security issues in the Horn. Furthermore the pro-life ration of small arms, the border disputes, and cross border interventions involving pastoralist communities undermine the regional peace and security interventions of IGAD.

\section{Reference}

Gibert, Marie (2006): The European Union in the IGAD-Sub region: Insights from Sudan and Somalia, in: Review of African Political Economy, vol. 33, no. 107.

Healy, Sally (2008): Lost Opportunities in the Horn of Africa: How Conflicts Connect and Peace Agreements Unravel. London: Chatham House.

, (2011a): Horn of Africa: Hostage to Conflict-Security and Economic Interdependence. London: Chatham House.

Griffard, Bernard and John Troxell (2009): Enhancing Professional Military Education in the Horn of Africa: The Ethiopian Defense Command and Staff College Initiative. Center for Strategic Leadership Issue Paper, US Army War College.

Lyons, Terrence (2009): The Ethiopia-Eritrea Conflict and the Search for Peace in the Horn of Africa, in: Review of African Political Economy, no. 120.

Kidist Mulugeta (2011a): The Role of Regional and International Organizations in Resolving the Conflict in Somalia: The Case of IGAD. Study Prepared for the Friedrich Ebert-Stfung Addis Ababa Office. , (2011b): The Ethio-Eritrean War: An Analysis of its Causes, Course, Impacts and Prospects, in Roba Sharamo and Berouk Mesfin (eds.): Regional Security in the Post-Cold War Horn of Africa. Addis Ababa: Institute for Security Studies.

Medhane, Tadesse (1999): The Eritrean-Ethiopia War: Retrospect and Prospect. Addis Ababa: Mega Printing Enterprise.

Wakengela, Mupenda (2011): Keeping an Elusive Peace: AMISOM and the Quest for Peace in Somalia, in Roba Sharamo and Brouk Mesfin (eds.): Regional Security in the post-Cold War Horn of Africa. Addis Ababa: Institute for Security Studies. 
United Nations Development Programme (2013): Human Development Report: The Rise of the South Human Progress in a Divers World.

United Nations Security Council (2011): Resolution 2023 (2011), Reinforcing Sanctions Regime against Eritrea "Calibrated" to Halt All Activities Destabilizing Region. New York: United Nations. 